\title{
Extensive Reading for University EFL Learners: Its Effects and Both Teachers' and Learners' Views
}

\author{
Chaochang Wang \\ Ming Chuan University, Taiwan \\ Chu-Tai Ho \\ Ming Chuan University, Taiwan
}

\begin{abstract}
The effect of reading on general communicative competence remains a focus of second language acquisition research. Extensive reading, in particular, provides rich input and helps learners acquire languages. Research has provided findings that support the value of extensive reading (ER); however, there is scant evidence to date showing the relationship of extensive reading to overall competence and, particularly, writing competence. The present study investigated the relationship of ER to overall English language competence as well as teachers' and students' views about its implementation. The participants were 190 Taiwanese university freshmen and their three English instructors. The data includes scores on pre- and post-tests measuring students' listening, reading, and writing as well as questionnaire responses and interview accounts. The findings of the study indicate that the effectiveness of ER for the student participants is partially supported and, hence, have implications for English teaching and learning in EFL contexts.
\end{abstract}

Index Terms - extensive reading, reading, EFL teaching / learning, Taiwan English language teaching, language testing, learner attitudes, learner perceptions

\section{INTRODUCTION}

The process of learning a second language for most learners is one generating various emotions: excitement, uncertainty, frustration, etc. While many are blessed to have overcome difficulty in learning the language and shown confidence in using it, others may either feel powerless and suffer from this feeling or give up learning the language at all. What contributes to the language learning process and eases learner anxiety has been a major concern to people involved in language education.

Research in second language acquisition (SLA) has investigated possible factors impacting language learning and built up theories of second language learning. Continued efforts in finding answers to the puzzles of language learning (Brown, 2014) and their implications to learning and teaching have been taken. One area among many that have drawn research attention is extensive reading. Extensive reading (ER) provides rich input (Krashen, 1982, Krashen \& Terrell, 1983) and helps equip learners with necessary skills to gain information, make connection with the world, and, thereby, feel empowered. Such reading practice has to be done extensively whether it is included in a second language curriculum "as a separate, stand-alone course" or "as part of an existing reading course" (Day \& Bamford, 1998). Krashen (1993) has called ER pleasure or "free voluntary reading" and defined it as "rapid reading for main ideas of a large amount of text" (Krashen \& Terrell, 1983, p. 134). Anderson (1996) uses a different term from Krashen's "wide reading." Day and Bamford (1998) see ER as a reading process that helps develop language ability, a reading habit, and positive attitudes toward reading. Namely, extensive reading is reading in quantity and for meaning, reading that involves self-controlled reading and low-anxiety demands. It has gained widespread support in language teaching due to its practice in accordance with theory of language acquisition, its effect in empowering learners, and many research findings encouraging its implementation.

\section{A. Extensive Reading and Its Impact on SLA}

The rationale for the inclusion of ER in language learning and teaching is in line with theory of SLA and supported by research findings.

Schema theory, for example, informs us of the way readers may construct meaning. Its central point is that a text does not carry meaning itself. It is the reader who brings the so-called schemata to the text. What constitutes schemata may include the reader's knowledge of the world, culture, emotion, personal experience, etc., which help the reader to make meaning with the printed text (Brown, 2001). Thus, texts with contents and linguistic forms related to the reader's prior knowledge or meeting the reader's interest make the reading process an easy one. Extensive reading with an emphasis on the freedom for the reader to select his/her own reading and read on his/her own pace makes the reading act a meaningful one and makes it possible for the reader/learner to make an optimal amount of reading.

Human learning theory also provides support for the inclusion of ER into language learning programs. Ausubel (1968) indicated that learning must be meaningful learning in order to retain what is learned; that is, the new information or 
items should be made related to the learner's existing cognitive structure or prior knowledge. According to Ausubel, retention is far more possible when the newly learned is "subsumable" to one's cognitive structure. Hence, "subsumption," association in nature, is the key to meaningful learning, to which extensive reading is relevant. The topic / content and the linguistic part of the selected text in the free voluntary reading activity are relatable to the reader / learner's cognitive system. Accordingly, the nature of ER promotes language learning.

In connection with meaningful learning theory is Krashen's (1982, 1993, Krashen \& Terrell, 1983) input theory (currently termed as "comprehension hypothesis"). According to Krashen, optimal language learning takes place when learners undergo an acquisition (or subconscious) process in contexts rich in comprehensible input and low-anxiety air. Central to his theory is the comprehensible input hypothesis $(i+1)$. Input for learners in terms of the receptive aspects of learning is better to be a little beyond learners' current language competence. Another major hypothesis in Krashen's theory is his affective filter hypothesis. For language acquisition to take place, the "affective filter" according to Krashen must be low, or learners will be overwhelmed with the learning of the new language. Undoubtedly, ER exposes learners to rich comprehensible input and engages them in reading in a non-threatening way. In fact, Krashen (2004) has put much emphasis on free reading and greatly promoted extensive reading due to its tremendous impact on learning.

In addition to language skills and language-related effects, extensive reading is closely related to the affective aspects of learning. Learners' confidence and perceived identity in learning a new language may all affect learning outcomes.

Paulo Freire (1993; Freire \& Macedo, 1995) has proposed "The Pedagogy of the Oppressed" and indicated the importance of making learning relevant to learners' existent and experiential world. His propositions about education to empower learners by making learning relevant to them justify the implementation of extensive reading, which engages learners in reading texts of their own interest and proficiency level. In the reading process, they can gradually develop their confidence in not only learning the language but also making connection with the world with their growing ability of reading and knowledge about the world.

\section{B. Previous Research}

Much research has been conducted to investigate the relationship of extensive reading and language ability.

In Lee, Krashen, and Gribbons (1996), language ability was defined as performance on the tests measuring the restrictive relative clause competence. Meaningful to find is extensive reading was found to be the only predictor of performance on the tests. Leung's (2002) case study investigated extensive reading and its relationship with adult's self-study of Japanese over a 20 -week period. Results indicate vocabulary and reading ability to have been affected with the practice of extensive reading. Hayashi's (1999) study revealed similar results despite its different research design from Leung's. The pre- and post-tests had results showing that the more self-selected books students read the greater improvement they experienced in reading and vocabulary. Hong and Wang's (2007) diary study of a female adult learning French through ER reported her improvement in reading, listening, speaking and writing. Tsang (1996) compared the effects of reading on writing performance among three English programs. They were a) regular plus unrelated enrichment program, b) regular plus extensive reading, c) regular plus frequent writing practice. Results showed that program $b$ was more effective than the other two.

Extensive reading not only helps enhance vocabulary and reading ability, writing, as well as grammatical competence (e.g., restrictive relative clause) but also other aspects of language competence. $\mathrm{Ng}$ and Sullivan (2001) reported studies comparing children in two language programs, REAP (the Reading and English Acquisition Program) and NON-REAP, the former with an emphasis on extensive reading. Results showed REAP children outperformed NON-REAP ones in all language skills. Lituanas, Jacobs, and Renandya (1999) studied the effects of extensive reading for remedial students. Sixty students were assigned to two groups. Both groups received 40-minute regular English teaching, with one group getting another 40 minutes of intensive reading and the other group getting extensive reading practice of the same amount of time. Results favored the extensive reading group. The pre- and post-tests design yielded a statistically significant difference between the two groups. Another study by the same researchers (Renandya, Rajan, \& Jacobs, 1999) examining the impact of ER on English learning of Vietnamese government officials has findings that support the implementation of ER in language programs.

Research studies related to the effect of ER on language learning are numerous. Many had findings demonstrating the positive effect of ER on language competence; quite a few (e.g., Lightbown, Halter, White, and Horst, 2002; Shih, 2015; Williams, 2007) could not yield significant results. For example, Shih (2015) examined the impact of extensive reading on college students' English reading proficiency and found there was no positive effect of extensive reading on reading proficiency whereas the experimental group improved their use of reading strategies. Further, Williams (2007) examined effect of ER programs for primary school students with a time-lapse design and found the retesting results decreased four years after the testing results. There are also studies (e.g., Davis, 1995; Day \& Bamford, 1998; Leung, 2002) pointed out difficulties of its implementation and reasons for its failure. Nevertheless, measuring the results of most studies on ER effect, ER has positive effects in general on reading proficiency, all language skills, vocabulary sizes, reading rate gains, and the use of reading strategies.

Research on extensive reading also includes its relationship with affective factors. Krashen (1993, 1994; Krashen \& Terrell, 1983) highly promotes extensive reading for its nature of entailing subconscious learning, comprehensible input and low affective filter, the latter being very likely the crux for the learner to sustain efforts. Previous research studies have provided findings related to extensive reading and attitude (e.g., Al-Homoud \& Schmitt, 2009; Alshamrani, 2003; Camiciottoli, 2001; Crawford Camiciottoli, 2001; Ji-Eun , 2009; Junko, 2013; Leung, 2002; McQuillan, 1994; Ng \& Sullivan, 2001; Yang, 2001). 
McQuillan (1994) elicited 49 learners' attitudes toward grammar exercises and extensive reading of popular literature. Results show that learners perceived extensive reading to be more "beneficial" for language acquisition and more "pleasurable" than the grammar exercises. Yang's (2001) comparison study had findings of not only English proficiency gains but also motivational benefits. Leung's (2002) diary study mentioned above also showed that extensive reading of an adult promoted a positive attitude toward reading. Alshamrani (2003) investigated nine learners' attitudes toward extensive reading of authentic texts and found that they had positive attitudes toward the reading activity and were motivated to continue extensive reading in the future.

Encouraging and attempting as it may seem for teachers and practitioners, little research on extensive reading has been conducted on a large sample to identify its relationship with second language ability, in particular, writing competence. In addition, learner resistance as a source of difficulty in implementing extensive reading has been documented (Leung, 2002; Day \& Bamford, 1998). However, learners' attitudinal (or affective) change and its relationship with the amount of reading are seldom visited. Thus, this research aimed to study 1) the relationship of extensive reading practice and English language competence, particularly writing ability, 2) reading teachers' perceptions about the extensive reading component as well as learners' perceptions of this practice including their attitude toward extensive reading, perceived importance and effect of extensive reading, their confidence gains, etc. Also proposed to investigate was 3) student participants' perception change before and after the implementation of extensive reading in their first-year reading program. Accordingly, the research questions this study addresses are as follows:

1) What is the relationship of extensive reading and English language proficiency, in particular, writing ability?

2) How do student participants perceive extensive reading as a component of their reading programs before and after the ER implementation? Do their perceptions change after the ER implementation for one year?

3) How do the reading teachers perceive extensive reading and its implementation in their reading class?

\section{METHODOLOGY}

A mixed research design that included the pre- and post-test method and a qualitative research method was employed in the present study. Participants of this study were invited to take ELTS-developed tests (listening and reading tests) as well as a writing test before and after the 2-semester implementation of extensive reading. Meanwhile, after taking the pretests and posttests, they were also asked to respond to a questionnaire examining their perceptions /attitudes toward the extensive reading practice that was required for all freshman and sophomore English majors. (See the design for the quantitative part of the research in Table 1). In the end of the second semester, interviews with the instructors were conducted and tape-recorded.

TABLE I.

RESEARCH DESIGN FOR THE QUANTITATIVE PART OF THE STUDY

\begin{tabular}{|c|c|c|c|c|c|c|}
\hline Test & \multicolumn{2}{|c|}{ Pretest } & \multicolumn{2}{|c|}{ Posttest } & \multirow[t]{3}{*}{ gain } & \multirow[t]{2}{*}{$t$} \\
\hline & Me & StD & Mean & StD & & \\
\hline \multicolumn{6}{|l|}{ Listening } & \\
\hline \multicolumn{7}{|l|}{ Reading } \\
\hline \multicolumn{7}{|l|}{ Writing } \\
\hline \multirow[t]{2}{*}{ Attitude } & \multirow[t]{2}{*}{ Pretest } & & Posttest 1 & Posttest 2 & Posttest 1 Posttest 2 & Posttest 1 \\
\hline & & & Mean $\quad$ StD & Mean StD & & \\
\hline
\end{tabular}

\section{A. Student Participants}

Subjects of the study were 190 freshman English majors at a northern university in Taiwan. They were from four intact classes. Most of them were newly graduated from senior high schools with a similar English education background. Their English proficiency was roughly between low to high intermediate levels. Although the department made a reading policy of implementing extensive reading for all freshman and sophomore students, only the freshman students were invited for this study, and the reason was because of the nature of this study being interested in their novice experience of extensive reading.

\section{B. The Reading Program and the Teacher Participants}

The English-major program of this northern university has implemented extensive reading to both their freshman and their sophomore students for several years. Based on this policy, a requirement of both freshman and sophomore reading courses was for students to read on their own graded English books or teenager-literature books particularly bought and reserved in the library for the English majors in the university. Ideally, after reading a book, a student would write a report about it or do other kinds of writing (e.g., keeping a reading log) depending on what their instructors require them to do. In addition, the minimum number of books for each student to read varied with the requests of individual instructors. And the instructors teaching freshman reading may be different every year. How teachers conducted extensive reading and integrated it into their reading courses was taken as a variable affecting the amount of extensive reading and learners' competence in English. Information about the reading instructors' background was shown in Table 2. 
TABLE II.

INSTRUCTORS' BACKGROUND

\begin{tabular}{lllll}
\hline Teacher & Class & Gender & Minimum N. of books & Educational background \\
\hline Teacher 1 & Class A \& B & F & 24 & Ph.D. in Education \\
Teacher 2 & Class C & F & 10 & M.A. in TESL \\
Teacher 3 & Class D & F & Around 10 & Ph.D. in Applied Linguistics \\
\hline
\end{tabular}

\section{Instruments for Quantitative Data Collection}

The reading and listening tests developed by English Learning Testing Service (ELTS) in Taiwan were conducted in the beginning of the first semester and a post-test in the end of the second semester. The test consisted of listening (40 items) and reading (30 items). Instrument reliability was given using KR-20 (Henning, 1987) for the ELTS tests. Table 3 displays the reliability coefficients, which are satisfactory because according to Gay (1976) and Sax (1989) a test or a questionnaire should have a reliability coefficient above 0.6 .

TABLE III.

RELIABILITY COEFFICIENTS OF LISTENING, READING, AND WRITING TESTS

\begin{tabular}{llll} 
& \multicolumn{2}{c}{ RELIABILITY COEFFICIENTS OF LISTENING, READING, AND WRITING TESTS } \\
\hline & Listening & Reading & Writing \\
\hline Pretest & 0.70 & 0.64 & 0.67 \\
Posttest & 0.64 & 0.62 & 0.71 \\
\hline
\end{tabular}

In addition, students were requested to take a pretest and posttest of writing. Each contains two different writing tasks, i.e., an essay and a letter writing tasks. Henning (1987) indicates that the more the modes of tasks included in a writing test, the more likely it exhibits test validity. After the subjects completed each writing test in which they were guided to produce one-paragraph writing and a letter, three English speakers teaching at the same University were invited to rate the collected writing data based on the degree each subject's writing being interesting, informative and fluent, with a rating scale of 2-14 points. That is, a holistic mode of scoring was employed. The writing data were scored based on the following scale modified from Melendez (1993):

$2=$ for only several phrases produced, those that are not meaningful

3-4 = for only several short sentences produced, those that show an attempt to produce information

5-8 = for a complete paragraph or a letter, one that provides meaningful or interesting messages though sentences in it are not necessarily logically connected.

$9-10=$ for a complete paragraph or a letter that is meaningful or interesting with sentences logically connected.

11-14 = for a complete paragraph or a letter that is either very meaningful or very interesting, or both with sentences logically connected.

The inter-rater reliability for the writing test was estimated using Spearman-Brown Prophecy formula. The reliability coefficients of the pretest and posttest are 0.67 and 0.71 respectively.

Questionnaires were employed to investigate student participants' perceptions of extensive reading. The questionnaire was pilot-tested to a group of 54 students first and improved for the formal study. It consisted of background information questions, forty-four perception items accompanied by a seven-point scale in the Likert format, as well as two open questions. The reliability coefficients were estimated and display in Table 4.

TABLE IV.

RELIABILITY COEFFICIENTS OF THE QUESTIONNAIRE

\begin{tabular}{|c|c|c|c|c|c|}
\hline & Attitude & Importance & Effect & Confidence & Total \\
\hline \multicolumn{6}{|l|}{ Attitude } \\
\hline Pretest & 0.83 & 0.87 & 0.93 & 0.92 & 0.96 \\
\hline Posttest 1 & 0.86 & 0.87 & 0.93 & 0.92 & 0.97 \\
\hline Posttest 2 & 0.86 & 0.82 & 0.92 & 0.92 & 0.96 \\
\hline
\end{tabular}

\section{Instruments for Qualitative Data Collection}

To understand how individual instructors implement the department's reading policy, two semi-structured interviews of 40 50 minutes were conducted to each of them in the end of each semester. A protocol of interview questions was developed on the basis of needs.

To implement the extensive reading program to the freshman and sophomore students, the program has purchased around five hundred English readers, including various graded series of novels and stories as well as books related to children and teenager literature. Before the study was done, the library had bought almost two thousand books for this reading purpose.

\section{E. Data Analysis}

The pretest and posttest data collected with the use of ELTS tests, the writing test, and the questionnaire were analyzed using statistical procedures.

The interview data were transcribed verbatim. According to Spradley (1979), a verbatim record of interview data is important for the investigator to be confident about findings. The analytic process included repeatedly reading the transcriptions, coding, making comparisons, and making connections between categories emerging from the data, following the content analysis method (Dörnyei, 2007). 


\section{RESULTS}

The study results are presented to address each of the research questions.

Research question 1: What is the relationship of extensive reading and English language proficiency, in particular, writing ability?

Table 5 lists test results and learner attitudes. Analysis of test results using paired $t$-test indicated significant gains in students' listening, reading, and writing abilities. Listening ability reflected by the listening posttest results was significantly higher than it was measured by the pre-test (posttest $\mathrm{M}=81.06 \mathrm{SD}=8.08$ pretest $\mathrm{M}=74.23 \mathrm{SD}=9.99 t=11.71$ $\mathrm{p}<0.01$ ). Results of the reading posttest were also significantly better than those of the pretest (posttest $M=83.02$ $\mathrm{SD}=7.90$ pretest $\mathrm{M}=78.45 \mathrm{SD}=8.12 \mathrm{t}=8.56 \mathrm{p}<0.01$ ). Similarly, average scores of the two writing tests indicated a significant gain in writing (posttest $\mathrm{M}=17.23 \mathrm{SD}=1.77$ pretest $\mathrm{M}=15.81 \mathrm{SD}=2.12 t=7.56 \mathrm{p}<0.01$ ). The increased English ability may be a result of implementing extensive reading in the reading class for one year.

However, the single-group, pretest-posttest design in this study may have displayed a weak one. The gain in English ability can be attributed to factors like the implementation of extensive reading. However, it may also be a result due to "the process of maturation" (Hatcher \& Stepanski, 1994, p. 196).

TABLE V.

IMPACT OF EXTENSIVE READING AND LEARNER ATTITUDES

\begin{tabular}{|c|c|c|c|c|c|c|}
\hline \multirow[t]{2}{*}{ Test } & \multicolumn{2}{|l|}{ Pretest } & \multicolumn{2}{|c|}{ Posttest } & \multirow[t]{2}{*}{ Gain } & \multirow[t]{2}{*}{$t$} \\
\hline & M & SD & M & SD & & \\
\hline Listening & 74.23 & 9.99 & 81.06 & 8.08 & 6.83 & 11.71 ** \\
\hline Reading & 78.45 & 8.12 & 83.02 & 7.90 & 4.56 & $8.56^{* *}$ \\
\hline Writing & 15.81 & 2.12 & 17.23 & 1.77 & 1.42 & $7.56^{* *}$ \\
\hline
\end{tabular}

In order to further explore the relationship between extensive reading activity and learning outcomes, Table 6 presents information of the minimum number of books students were required to read by different teachers as well as the average number of books they actually read. ANOVA analysis of pretests and posttests at the three levels, i.e., listening, reading, and writing ones, showed no significant difference in the test means of individual classes. It also yielded no significant results in the gains of test scores of the four classes except in those of the writing tests. Tukey's HSD test showed that students in Class B had a significantly higher average gain score in writing than that of the students in Class D. The result implies the higher reading requirement (24 books) and averagely more books read (14.52 books) may have resulted in more writing improvement of students in Class B than students in Class D with less reading requirement (8-10) and fewer books read (7.44).

TABLE VI.

ANALYSIS OF VARIANCE AND NUMBER OF BOOKS REQUIRED TO READ

\begin{tabular}{|c|c|c|c|c|c|c|c|c|c|}
\hline & \multicolumn{4}{|c|}{ Teacher 1} & $\begin{array}{l}\text { Teacher } \\
\text { Class C }\end{array}$ & 2 & $\begin{array}{l}\text { Teacher } \\
\text { Class D }\end{array}$ & & F-ratio \\
\hline & $\mathrm{M}$ & SD & $\mathrm{M}$ & SD & M & SD & M & SD & \\
\hline $\begin{array}{l}\text { Minimum number of } \\
\text { books required }\end{array}$ & 24 & & 24 & & 10 & & $8-10$ & & \\
\hline $\begin{array}{l}\text { Average number of books } \\
\text { read }\end{array}$ & 16.23 & & 14.52 & & 9.65 & & 7.44 & & $18.86 * *$ \\
\hline Attitude pretest & 228.35 & 32.26 & 221.27 & 37.80 & 212.6 & 28.99 & 213.93 & 36.67 & 2.22 \\
\hline Attitude posttest 1 & 210.39 & 31.53 & 203.26 & 34.72 & 194.55 & 29.52 & 213.15 & 34.94 & 2.60 \\
\hline Attitude posttest 2 & 207 & 28.42 & 214.21 & 29.39 & 193.58 & 29.64 & 201.53 & 28.35 & 2.54 \\
\hline Listening pretest & 73.73 & 11.08 & 73.78 & 9.35 & 72.40 & 10.00 & 76.05 & 9.13 & 1.22 \\
\hline Listening posttest & 82.35 & 7.17 & 79.45 & 6.77 & 79.36 & 8.43 & 82.86 & 8.96 & 2.74 \\
\hline Reading pretest & 78.07 & 8.80 & 78.51 & 7.89 & 78.49 & 6.97 & 79.47 & 8.26 & 0.28 \\
\hline Reading posttest & 81.33 & 9.62 & 83.15 & 6.05 & 84.59 & 7.28 & 82.91 & 7.67 & 1.35 \\
\hline Writing pretest & 15.60 & 2.41 & 15.14 & 2.39 & 15.92 & 1.80 & 16.20 & 1.69 & 2.04 \\
\hline Writing posttest & 17.12 & 1.81 & 17.43 & 1.61 & 17.45 & 1.81 & 16.96 & 1.80 & 0.78 \\
\hline Gain in listening & 8.57 & 8.17 & 4.78 & 6.86 & 7.15 & 8.77 & 6.33 & 6.82 & 1.66 \\
\hline Gain in reading & 3.33 & 5.72 & 5.48 & 7.14 & 6.22 & 7.06 & 3.43 & 7.74 & 2.01 \\
\hline Gain in writing & 2.16 & 2.78 & 3.08 & 2.54 & 2.17 & 1.75 & 1.14 & 2.31 & $5.03 * *$ \\
\hline
\end{tabular}

Research Question 2: How do student participants perceive extensive reading as a component of their reading programs? Do their perceptions change after the ER implementation for one year?

Results in Table 7 regarding learners' perceptions about the inclusion of extensive reading in their reading class show their views were significantly positive both before and after the ER implementation. Table 8 indicated learners tended to hold a favorable attitude toward extensive reading in the three questionnaire investigations, perceive it to be important and effective to learning, and have confidence in its effect. All the mean scores obtained in the three investigations were significantly higher than the hypothetical means $(\mu)$. Learners held substantially supportive views in the beginning of the first semester after their individual reading teachers explained how ER was to be implemented, and their views remained highly positive in the end of the second semester though their views also decreased with time reflected in the three investigations. The change in learner attitude detected in the pre- and posttests may be due to their high motivation for the activity in the beginning and the pressure of meeting the requirement of reading the minimum number of books set by individual instructors. Even so, comparing the mean scores of the three questionnaire results including the 
component means with their hypothetical means $(\mu)$, their overall attitudes / perceptions of ER were very positive.

TABLE VII.

STUDENTS' ER ATTITUDES

\begin{tabular}{|c|c|c|c|c|c|c|c|c|c|}
\hline Pretest & & Posttest & & Posttes & & Gain & & $t$ & \\
\hline M & SD & M & SD & $\mathrm{M}$ & SD & Posttest 1 & Posttest 2 & Posttest 1 & Posttest 2 \\
\hline 218.92 & 34.11 & 205.62 & 33.04 & 204.61 & 29.40 & -14.30 & -15.31 & $-5.02 * *$ & $-4.62 * *$ \\
\hline
\end{tabular}

TABLE VIII.

STUDENTS' FOUR-ASPECT ATTITUDES

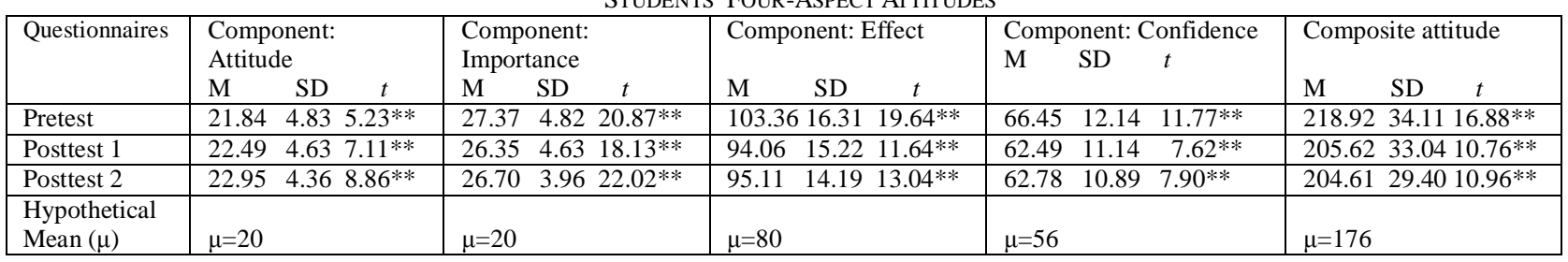

Regarding the attitudinal differences among the student participants in the four different classes shown in Table 6 above, it is interesting to find the number of books required and actually read did not result in difference in attitude.

Research Question 3: How do the reading teachers perceive extensive reading and its implementation in their reading class?

The three teachers of the four freshman reading classes had a passion for their implementation of ER to a different degree. Teacher 3 was very enthusiastic about and devoted to promoting ER; teacher 1 also took pleasure in including ER in her reading classes though not so enthusiastic as teacher 3; while teacher 2 was relatively passive in implementing the departmental policy. Analysis of the interview responses reveals several themes that affect teachers' attitude toward ER for their reading classes. They are teacher confidence in applying ER to their reading classes, ER implementation strategies, perceived impact of ER on English learning, and teachers' future improvements.

Confidence in ER implementation. Both Teacher 1 and Teacher 3 were confident in doing ER-related activities with students. Sources of their confidence may include their belief in its impact on reading and language ability as well as their continued effort in keeping themselves informed by research and theory of ER. Teacher 1 had her initial contact with ER theories at a workshop in Hawaii in 2003 and has started its implementation since then.

Excerpt 1: "I have been to Richard Day's workshop. He is a person of enthusiasm that is infectious. So I think I can do the same thing like him."

She believed in the positive impact of ER on language learning and had developed an English reading habit herself. She said, "I like reading anything English no matter what it is about...." During the year of including ER in her reading classes for this study, she constantly consulted books and research papers for ideas and methods to improve her skills of promoting ER. She not only read research for ideas but also bought recommended books of ER activities for her ER teaching.

Various ways to get students tuned in ER typically introduced in Day and Bamford (1998). Teacher 3 was also confident in and positive about teaching with ER. She indicated that she became more and more confident in teaching ER as time went on. She said, "I feel more and more confident in implementing ER in my reading class." She sought ideas from relevant literature and developed her own approach to engaging students in reading extensively. In her class, students shaped their own groups and chose and read the same books with their group members. Books chosen were often graded literary books either recommended by her or by their peers in the group-sharing time. This way of promoting ER was termed "literary circle." Student read at home and for much of the class time. In her reading class, more than half of the time was for ER-related activities. Students read together, shared their reaction, talked about the stories in books, and even played out the story they read. Thus, students not just read but also talked much in class. It was a creative way to involve students in reading. She not only looked for ideas in research but also conducted her own research on ER using literacy circles.

Despite her low confidence, teacher 2 tried her best to implement ER. She said, "I didn't do well this year.... I was supposed to spend some class time on ER activities.... I really can't." Though not confident about her own ER implementation, she promoted the basic form of ER in her class, meeting a minimum request of the department policy. She set a minimum number of books (i.e., 5 books one semester) for students to complete reading and demanded a report for each book written in a flexible way. No class time was spent on ER activities. According to her interview responses, she knew ER's effect on language learning, but she had little idea how she could engage students in reading extensively. Students' reports on books were even allowed to be replaced by reports on teacher handouts and films they watched. "I'm a little rascal in accepting students' reports when they asked whether it's ok to write about films or something else, I agreed." Responses showing her feeble confidence on her own implementation were sporadic in the interview with her.

Individual teachers' ER implementation. The teacher participants' way of implementing ER may well reflect their confidence and attitude as mentioned above, and despite some common strategies, their way differed from one another.

All the three teachers had their students turn in a written assignment on each of the books they chose to read. However, the assignment varied from teacher to teacher. Teacher 1's students were requested to keep a reading $\log$ 
listing the books they had read and a short reflection on each as well as written reports on 3 books from the reading list in one semester. The minimum number of books was 12. Each report may have been a reaction to a major character or a summary of the story plus a feedback in any form.

Teacher 3 had her students read 4 to 5 books a semester and a written report on each book. Each report varied depending on what instruction the teacher gave.

Similarly, teacher 2 assigned students to read five books a semester, and $15 \%$ of the course grade was given based on the written reports on the books. Each report could be in any format of the one hundred ways of writing a book report introduced by the teacher in the beginning of the semester.

Basically, a teacher only needs to set a minimum number of books for students to read and set their own strategies to score their extensive reading, such as a written report for each book read and a reading log, in order to implement the departmental policy of ER. For example, teacher 2 adopted this basic form of ER in her reading class; i.e., she collected students' writing on their chosen books toward the end of the semester and gave their ER scores based on the number of books they read evidenced by their book report.

In addition to meeting the departmental requirement for all reading classes, both teachers 1 and 3 did ER activities in class almost every week. Two components rotated in class: Extensive reading activities and reading strategy-based activities. In the beginning, class time tended to be equally distributed; yet as time went on, more was on ER as was requested by the students. ER activities included in their classes were many. For example, teacher 1 employed time repeated reading, 5-minute silent reading, reading and anticipating what's going to happen, group discussion, etc. Teacher 3 motivated her students by putting them in small groups called "little literacy circles." A group chose their own reading books and read them at a similar pace. Classroom ER activities, therefore, included reading with group members, swapping group members to form new groups and share books read, group sharing their responses to the books read to the whole class by means of either oral report or performance on the stage. The last form of ER activities was most appealing. Many of Shakespearian comedies and tragedies were adapted for stage performance. According to teacher 3, students were observed to be both serious about and devoted to their performance. Though the average number of books read by her students was smaller due to the group reading feature than those of other classes, esp., teacher 1's classes, speaking was well integrated into ER in the form of discussion, sharing, group oral report, and stage performance.

Perceived influence on language learning. All three teachers believed in the effect of ER on language learning. Nevertheless, they were not certain whether it was effective to their students after promoting ER in their classes for two semesters because they did not have objective evidence. However, they did indicate the positive influence perceived on their students.

All three teachers could sense students' positive attitude toward ER. They liked ER and its activities in class. When teacher 1 switched her teaching emphasis to strategy-based teaching, her students asked to do more ER in class. She said, "Students are less interested in strategy training and reading strategy training." She even canceled the scheduled curriculum on reading strategies for the last month and replaced it with pleasure reading. Same phenomenon applied to teacher 3's class. In the second semester, more of her class time was on ER because students were highly interested in it. Students even extended their gratitude to her for her devotion to ER teaching.

Another noted influence of ER on learning was students' reading habit. Although the habit of reading extensively may not have applied to all students, most were perceived to have formed the habit. Teacher 1 stated as follows regarding reading habit.

Excerpt 2: Sometimes when we were doing 'talk about the book,' I would ask them to reflect about.... Some stated that he (they) felt they would shape a reading habit.

Teacher 3 also indicated this ER implementation entailed many students' motivation to borrow the books recommended by their peers. She said, "Most students feel through ER they are motivated to borrow books, esp., those with very good comments from their peers." They became more aware of what reading was than before. Some with poor reading skills felt they could read faster; others asked to read more. The same teacher indicated, "There are relatively more students who consider their English ability to be poor feel they can read faster now."

Also noted was students' reading pleasure. As mentioned above, many students asked to do more ER in class whether it was reading silently or an ER activity. In addition, there were students asking for a reading list for the coming summer. Teacher 3 said, "I have students who came to me and asked me to recommend a list of books for the summer time reading." Students of teacher 3 were especially interested in ER in terms of their devotion to ER and its follow-ups, especially, the stage performance activity. Most of her students read and had a very good idea of Shakespeare's four tragedies and four comedies in the second semester and most were interpreted and performed on the stage. She could perceive her students' sense of achievements and pride in themselves raised after reading the books and performing on the stage. She also felt her students transformed from those depending on teachers in learning to those learning on their own, i.e., from passivity to activity. She said,

Excerpt 3: I want them all to be proud to tell others.... For example, during the year in the four tragedies and four comedies, he can say, it is "The Twelfth Night" that few students and others would know about. But through drama performance, almost all students wanted to read this book.... I hope they feel positive about themselves via this way... and about their reading... and take pride in telling others that 'I know this book.' I feel students have become ones who actively seek to acquire knowledge rather than depend on the teacher for knowledge.

Although all three teachers had no evidence showing ER's effect on their students' English learning and teacher 2 was uncertain about her students' attitude toward ER, perceived effects were spotted in terms of students' positive 
attitude toward ER, their reading habit formation, and their heightened reading pleasure observed.

Self-improvement in the future. All three teachers indicated change to be made in their future reading classes. Teacher 2 was positive about the implementation of ER and its effect but had little idea of how she could improve her reading class in the next school year for her new students except sticking to the basic form of ER implementation. However, she also showed her intention to consult with the other two reading teachers for more ideas to better her ER implementation.

For the other two teachers, due to their interest in ER-related research and capacity for implementing innovative teaching, their motivation to better their ER promotion was relatively high. Both indicated to raise the ER percentage in the course score, in particular, for teacher 3 to $60 \%$. Teacher 1 has indicated to raise the percentage to be more than $20 \%$.

They also indicated to increase group work in class for more interaction among students, i.e., for more speaking practice. Teacher 1 believed in the equal importance of output with the reading input. Teacher 3 inclined to use only ER books to replace a strategy-based textbook, implying most of the class time to be spent on ER-related activities in the future. Even teacher 2 who spent no time on ER activities in class revealed she would give some class time for students to share how they feel about books read.

\section{CONCLUSION}

The results of this study have partially supported ER in terms of its effect on learning outcomes, student attitude toward it, and teacher perception and have implications on language learning and teaching.

The pre-test and posttest design of this study did show statistically significant gains in the listening, reading, and writing test scores after the implementation of ER for one year. The results corroborate findings in previous research (Crawford Camiciottoli, 2001; Krashen \& Cho, 1995; Lee \& Krashen, Gribbons, 1996; Macquillan, 1994; Lituanas, Jacobs, \& Renandya, 1999; Renandya, Rajan, \& Jacobs, 1999; Young, 1999). Further analysis of ER's effect on individual classes revealed a significant difference in the progress in writing reflected in the pre- and post- writing tests. Students in Class A and Class B, taught by teacher 1, were required to read at least 24 books in the two semesters, and they actually read around 15 books in average, much higher than the average number of books read by students from the other two classes. The significant difference in the increased students' writing ability may be a result of the different numbers of books read by students. The more books students were required to read, the more likely they would read more and make more progress in writing. This result was further strengthened by the significant correlation between the number of books students read in the two semesters and their increased writing ability (the gain score in writing). Krashen (1993) has pointed out the power of extensive reading. Simply reading extensively will suffice for tremendous growth in language proficiency. Day and Bamford (1998) have similar views on the effect of ER alone in language learning.

Analysis of their questionnaire responses indicated their highly positive views about ER as a component of their reading classes. Most perceived the practice of ER in their reading classes to be favorable, effective in helping them to enhance their English skills, important for their learning, and helpful in raising their confidence in learning English. The results are in accordance with findings in previous research on learner attitude toward ER (Alshamrani, 2003; Crawford Camiciottoli, 2001; Leung, 2002; McQuillan, 1994; NG \& Sullivan, 2001; Yang, 2001). In addition, the instructor, who approached ER teaching differently, did not appear to be a factor of student participants' attitude toward ER.

As to teacher perceptions about ER, the interview accounts of the three teachers revealed a positive attitude toward ER. Although one teacher appeared to be less confident in including ER in her class, the other two teachers are relatively more devoted teachers in using ER. They had different approaches to implementing ER; however, students' reduced fear in reading, nurtured habit of reading, and positive attitude in ER were observed.

Also emerged from teacher accounts was teachers' move to access ER-related resources. One teacher had sought to learn innovative teaching in an overseas workshop, and later she further consulted theories and techniques for teaching with ER. There was another teacher of this study constantly looked for ideas to better her ER implementation. An enjoyable activity favored by both the teacher and her students was called "literacy circle," which entailed students" devotion to further reading. In sum of teachers' views about ER as a component of their reading classes, they have shown a positive attitude toward its implementation, substantial devotion to its promotion, and strong willingness to improve themselves in teaching with ER.

This study focusing on extensive reading and its relationship with English language learning and affective factors has results rich in insights into language teaching and learning as well as research relating to extensive reading. A positive relationship between the number of books read and learners' gain in writing ability was identified in this study, which information helps promote ER to wider population with confidence. Should a different relationship be identified, with care ER should be implemented. Both teacher and student participants' responses also revealed information guiding extensive reading practice. This study has also contributed to the research line regarding extensive reading in terms of its relationship with language ability, in particular, the writing ability, the subjects being English-majors different from those in most studies and its research design combining the quantitative and qualitative research methods for data collection and analysis.

Although the number of books individual students read had an effect on their writing tests, the pre- and post-test design also showed an increase in their English ability reflected on their test scores, and students' questionnaire responses exhibited a perceived positive effect on their English learning, this study has limitations future research needs to attend to. One limitation is that it did not employ a comparison research design that compares results of participant 
groups receiving different treatments. Future research on university students' extensive reading in similar contexts may use a quasi-experimental design to provide further evidence showing the relationship of extensive reading and English ability. Another limitation of this study is that its subjects being English-major freshmen who were exposed to different modes of English learning. Future research may consider sampling non-majors in order to limit the exposure they may have during the period when the research is conducted.

\section{REFERENCES}

[1] Al-Homoud, F., \& Schmitt, N. (2009). Extensive reading in a challenging environment: a comparison of extensive and intensive reading approaches in Saudi Arabia. Language Teaching Research, 13(4), 383-401. doi:10.1177/1362168809341508.

[2] Alshamrani, H.M. (2003). The attitudes and beliefs of ESL students about extensive reading of authentic texts. Unpublished doctoral dissertation, Indiana University of Pennsylvania.

[3] Anderson, R.C. (1996). Research foundations to support wide reading. In V. Greaney (Ed.), Promoting reading in developing countries (pp. 55-77). Newark, DE: International Reading Association.

[4] Ausubel, D.P. (1968). Educational psychology: A cognitive view. New York: Holt, Rinehart \& Winston.

[5] Brown, H.D. (2014, $6^{\text {th }}$ ed.). Principles of language learning and teaching. White Plains, NY: Pearson Education.

[6] Brown, H.D. (2001). Teaching by principles: An interactive approach to language pedagogy. White Plains, NY: Pearson Education.

[7] Camiciottoli, B. C. (2001). Extensive reading in English: habits and attitudes of a group of Italian university EFL students. Journal of Research in Reading, 24(2), 135.

[8] Crawford Camiciottoli, B. (2001). Extensive reading in English: Habits and attitudes of a group of Italian university EFL students. Journal of Research in Reading, 24(2), 135-153.

[9] Davis, C. (1995). Extensive reading: an expensive extravagance? ELT Journal, 49, 329-336.

[10] Day, R. R., \& Bamford, J. (1998). Extensive reading in the second language classroom. Cambridge: Cambridge University Press.

[11] DÖrnyei, Z. (2007). Research methods in applied linguistics. New York, NY: Oxford.

[12] Freire, P. (1993). Pedagogy of the oppressed. New York: The Continuum Publishing Company.

[13] Freire, P., \& Macedo, D.P. (1995). A dialogue: Culture, language, and race. Harvard Educational Review, 65, 377-420.

[14] Gay, L. R. (1976). Educational research: Competencies for analysis and application. Columbus, OH: Bell \& Howell.

[15] Hatcher, L., \& Stepanski, E. J. (1994). A step-by-step approach to using the SAS system for univariate and multivariate statistics. Cary, NC, US: SAS Institute.

[16] Hayashi, K. (1999). Reading strategies and extensive reading in EFL classes. RELC Journal, 30(2), 114-132.

[17] Henning, G. (1987). A guide to language testing. Boston: Heinle \& Heinle.

[18] Hong, S., \& Wang, C. (2007). An Introspective and Retrospective Journal Study of Extensive Reading. Paper presented at the 16th International Symposium on English Teaching, Taipei, Taiwan.

[19] Ji-Eun, C. (2009). The Effects of Extensive Reading on Enhancing Vocational High School Students' L2 Vocabulary \& Reading Rates. English Teaching, 64(3), 3-30.

[20] Junko, Y. (2013). Effects of extensive reading on reading attitudes in a foreign language. Reading in a Foreign Language, 25(2), 248-263.

[21] Krashen, S. (1982). Principles and practice in second language acquisition. New York: Pergamon Press.

[22] Krashen, S. D. (1993). The case for Free Voluntary Reading. The Canadian modern language review 50(1), $72-82$

[23] Krashen, S. (1994). The pleasure hypothesis. In J.E. Alatis (Ed.), Georgetown University Round Table on Language and Linguistics 1994 (pp. 299-322). Washington, D.C.: Georgetown University Press.

[24] Krashen, S. (2004). The power of reading. Englewood, CO: Libraries Unlimited.

[25] Krashen, S., \& Cho, K-S. (1995). Becoming a dragon: Progress in English as a second language through narrow free voluntary reading. California Reader, 29, 9-10.

[26] Krashen, S. D. \& Terrell, T.D. (1983). The natural approach: Language acquisition in the classroom. New York: Alemany Press.

[27] Lee, Y. O., Krashen, S., \& Gribbons, B. (1996). The effect of reading on the acquisition of English relative clauses. I.T.L. Review of Applied Linguistics, 113-114, 263-273.

[28] Leung, C.Y. (2002). Extensive reading and language learning: A diary study of a beginning learner of Japanese. Reading in a Foreign Language, 14(1), 66-81.

[29] Lightbown, P.M., Halter, R.H., White, J.L., \& Horst, R.H. (2002). Comprehension-Based Learning: The Limits of 'Do it Yourself.' Canadian Modern Language Review, 58 (3), 427-464.

[30] Lituanas, P. M., Jacobs, G. M., \& Renandya, W. A. (1999). A study of extensive reading with remedial reading students. In Y. M. Cheah \& S. M. Ng (Eds.) Language instructional issues in Asian classrooms (pp. 89-104). Newark, DE: International Development in Asia Committee, International Reading Association.

[31] McQuillan, J. (1994). How should heritage languages be taught?: The effects of a free voluntary reading program. Foreign Language Annals, 29, 56-72.

[32] Melendez, M.M. (1993). The effects of grammar instruction on learners' development of grammatical competence in a foreign language. Unpublished Ph.D. dissertation. The Pennsylvania State University.

[33] Ng, S.M. \& Sullivan, C. (2001). The Singapore reading and English acquisition program. International Journal of Educational Research, 35( 2), 157-167.

[34] Renandya, W. A., Rajan, B. R. S., \& Jacobs, G M. (1999). Extensive reading with adult learners of English as a second language. RELC Journal, 30, 39-61.

[35] Sax, G. (1989). Principles of educational and psychological measurement and evaluation. Belmont, CA: Wadsworth.

[36] Shih, Y. C. (2015). The impact of extensive reading on college business majors in Taiwan. The Reading Matrix, 15(1), $220-233$.

[37] Spradley, J.P. (1979). The ethnographic interview. New York: Holt, Rinehart and Winston.

[38] Tsang, W.K. (1996). Comparing the effects of reading and writing on writing performance. Applied Linguistics, 17(2), $210-233$.

[39] Williams, E. (2007). Extensive reading in Malawi: inadequate implementation or inappropriate innovation? Journal of 
Research in Reading, 30(1), 59-79.

[40] Yang, A. (2001). Reading and the non-academic learner: a mystery solved. System, 29(4), 451-466.

[41] Yorio, C. (1976). Discussion of "Explaining sequence and variation in second language acquisition." Language Learning, Special Issue Number, 4, 59-63.

[42] Young, D. J. (1999). Linguistic Simplification of SL Reading Material: Effective Instructional Practice? Modern Language Journal, 83, 350-366.

Chaochang Wang, the first author of this article, received a $\mathrm{PhD}$ degree in Applied Linguistics from the Pennsyvania State University in 2000. She has been teaching at Ming Chuan University since 1986 and is currently Associate Professor of Department of Applied English at Ming Chuan University, Taiwan. Her research interests include second language acquisition and teaching, language testing and program assessment, and research methods.

Chu-Tai Ho, the corresponding author, earned a Master's degree in TESOL from Teachers' College, Columbia University in 1986. She has been teaching at Ming Chuan University since 1987 and is currently lecturer of the Department of Applied English at Ming Chuan University. Her research interests include teaching English as a foreign language and language test development. 